\title{
Mapping of novel chromosomal regions associated with atopy
}

\author{
Cynthia Kanagaratham ${ }^{1 *}$, John Ren ${ }^{2}$, Pierre Camateros ${ }^{3}$, Rafael Marino ${ }^{3}$, Rob Sladek ${ }^{1}$, Silvia Vidal ${ }^{1}$, \\ Danuta Radzioch ${ }^{1,3}$
}

From Canadian Society of Allergy and Clinical Immunology Annual Scientific Meeting 2013

Toronto, Canada. 3-6 October 2013

\section{Background}

A panel of recombinant congenic strains (RCS) of mice can be used to study an array of disease related phenotypes [1]. We have used a panel of $33 \mathrm{AcB} / \mathrm{BcA}$ RCS, derived from parental strains $A / J$ and $C 57 \mathrm{BL} / 6 \mathrm{~J}$ (Figure 1), to study phenotypes of allergic asthma that are difficult to segregate in the human population, such as airway hyperresponsiveness [2]. Each recombinant strain is fully inbred and contains approximately $12.5 \%$ of the genome from one parental strain on the background of the other parental strain. Here we present our findings for mapping chromosomal regions associated with atopy, another phenotype of allergic asthma.

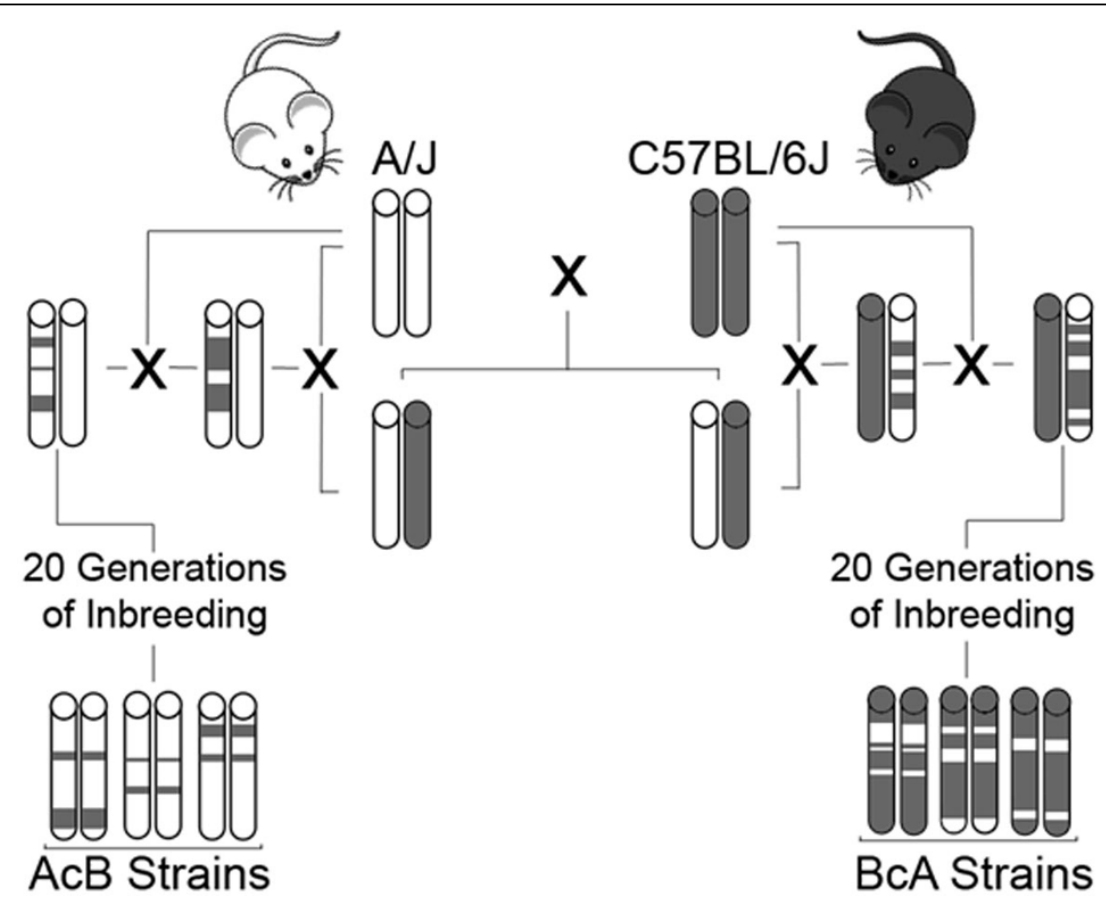

Figure 1 Generation of 33 RCS from atopic A/J and nonatopic C57BL/6J strains (adapted from [2])

\footnotetext{
* Correspondence: cynthia.kanagaratham@mail.mcgill.ca

'Department of Human Genetics, McGill University, Montreal Quebec,

Canada

Full list of author information is available at the end of the article
} 


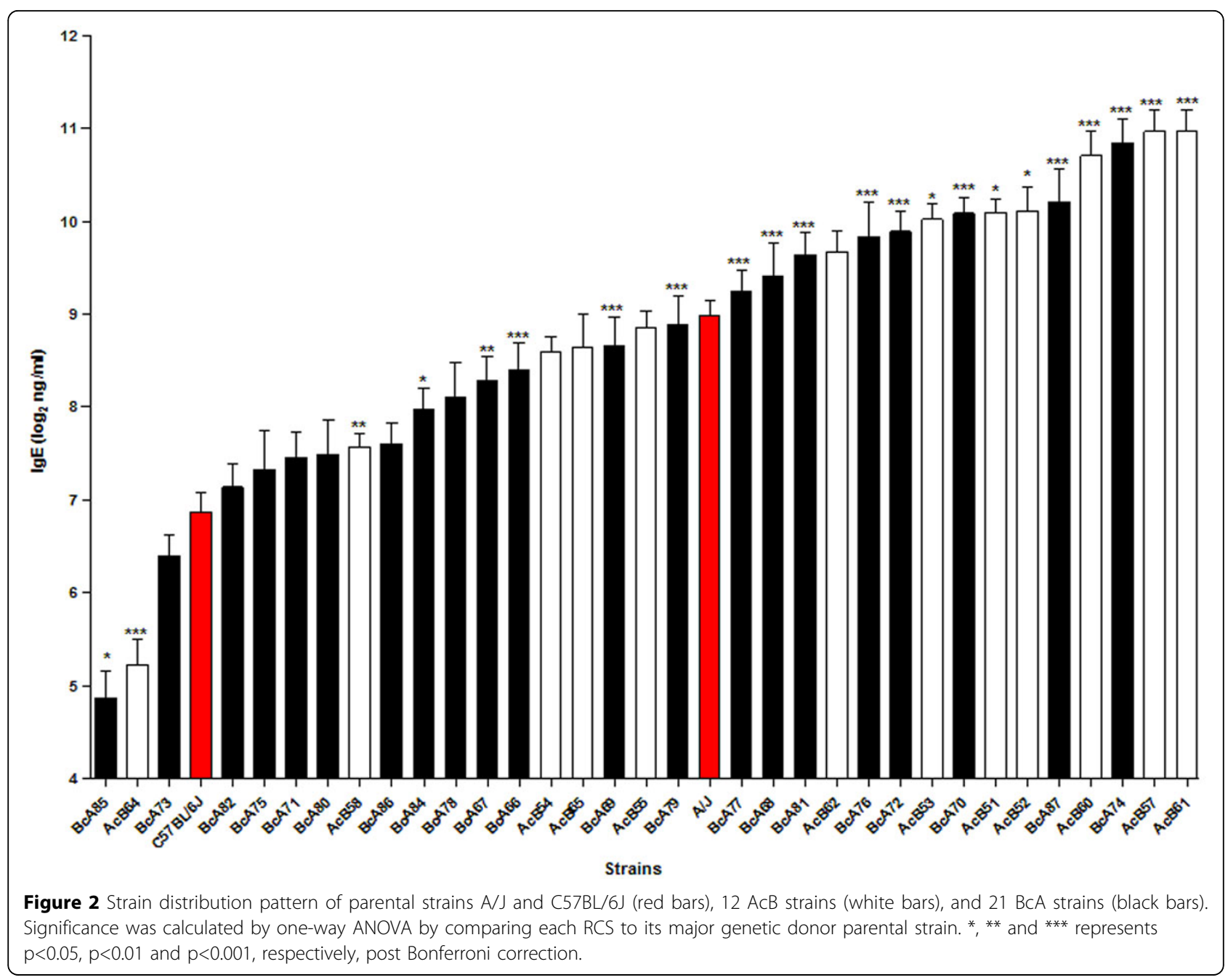

\section{Methods}

Naïve mice from each RCS were phenotyped for atopy by measuring plasma IgE concentration by ELISA. RCS mice were genotyped at 1215 markers that spanned the entire genome. Using the log transformed phenotype values and genotyping data, a marker-by-marker association analysis was performed to identify associations between the strain phenotype and genotype, while correcting for major background strain. Within the phenotype associated loci, candidate genes were selected based on the presence of coding mutations between the sequences of the two parental strains.

\section{Results}

$\mathrm{A} / \mathrm{J}$ and $\mathrm{C} 57 \mathrm{BL} / 6 \mathrm{~J}$ strains have significantly different plasma IgE concentrations. A/J mice have higher plasma IgE levels, making them a good model of atopic individuals. Among the 33 RCS, a wide distribution in plasma IgE concentrations was observed (Figure 2). Genotypephenotype analysis identified one region on chromosome
3 as significantly associated with atopy. This region contains a total of six protein coding genes of which four have coding variants in their sequences between $\mathrm{A} / \mathrm{J}$ and C57BL/6J strains.

\section{Conclusions}

To the best of our knowledge, we have identified a novel candidate loci associated with atopy. Future plans of our study include functionally validating the importance of our candidate genes, candidate locus, and of chromosome 3 in atopy. Our results demonstrate that using a genetically unique panel of RCS we can identify candidate genes that are in common and unique to the various phenotypes of allergic asthmatics.

\section{Authors' details}

'Department of Human Genetics, McGill University, Montreal Quebec, Canada. ${ }^{2}$ Department of Microbiology and Immunology, McGill University, Montreal, Quebec, Canada. ${ }^{3}$ Faculty of Medicine, Division of Experimental medicine, McGill University, Montreal, Quebec, Canada. 


\section{References}

1. Fortin A, Diez E, Rochefort D, Laroche L, Malo D, Rouleau GA, et al: Recombinant congenic strains derived from $A / J$ and $C 57 \mathrm{BL} / 6 \mathrm{~J}$ : a tool for genetic dissection of complex traits. Genomics 2001, 74:21-35.

2. Camateros P, Marino R, Fortin A, Martin JG, Skamene E, Sladek R, et al: Identification of novel chromosomal regions associated with airway hyperresponsiveness in recombinant congenic strains of mice. Mamm Genome 2010, 21:28-38.

doi:10.1186/1710-1492-10-S1-A52

Cite this article as: Kanagaratham et al:: Mapping of novel chromosomal regions associated with atopy. Allergy, Asthma \& Clinical Immunology 2014 10(Suppl 1):A52.

Submit your next manuscript to BioMed Central and take full advantage of:

- Convenient online submission

- Thorough peer review

- No space constraints or color figure charges

- Immediate publication on acceptance

- Inclusion in PubMed, CAS, Scopus and Google Scholar

- Research which is freely available for redistribution

Submit your manuscript at www.biomedcentral.com/submit
Ciomed Central 